\title{
ANALYSIS OF TREND IN WETLAND LOSS AND OTHER LAND-USE CHANGE IN PORT HARCOURT METROPOLIS, RIVERS STATE
}

\author{
Ogbuji, S. I. \\ Dept. of Geography and Environmental Management, \\ Imo State University, Owerri, Imo State, Nigeria. \\ DOI: https://doi.org/10.51193/IJAER.2021.7601
}

Received: 06 Nov. 2021 / Accepted: 13 Nov. 2021 / Published: 29 Nov. 2021

\begin{abstract}
Wetland loss and other land use change have been a major environmental concern over the past three decades as a result of human activities. This study analyzed the trend of wetland loss and other land use change in Port Harcourt Metropolis between 1990-2020, using Geographic Information System (GIS). To achieve this, research questions were postulated in order to achieve the aim of the study. The study utilized quasi-experimental design and made use of satellite imagery of Port Harcourt Metropolis of 1990, 2000 and 2020. The major land-use types identified in the study alongside wetlands include built up area, water bodies, farmland/sparse vegetation. The findings from the study revealed that in 1990 wetland occupied a spatial extent of $123.23 \mathrm{~km}^{2}$ (26.89\%) of the land use pattern of the study area. Consequently, in year 2020, there was dramatic change as wetland size reduced to $44.61 \mathrm{~km}^{2}(9.74 \%)$ of the total land-use pattern of the study area. Markov's probability of land-use change for 30 years (2020-2050) showed that the probability of wetland changing to a built up area in the next 30 years (2050), was $0.0049(0.49 \%)$. The study concluded that other land-use types especially built-up areas have continued to increased the rate and extent of wetland loss in the study area. The study recommended that adequate and continuous monitoring of wetlands by making use of satellite remote sensing should be encouraged in the study area. Also, there should be wetland protection and management policies with adequate enforcement mechanism.
\end{abstract}

Keywords: Analysis, Trend, Wetland loss, GIS, Port Harcourt

\section{INTRODUCTION}

Wetland ecosystem has been affirmed as a productive ecosystem of emergent vegetation. Wetlands are areas of marsh, fen, peat land or water, whether natural or artificial, permanent or 
International Journal of Agriculture and Environmental Research

ISSN: 2455-6939

Volume: 07, Issue: 06 "November-December 2021"

temporary, with water that is static or flowing, fresh, brackish or salt-water, including areas of marine within the depth not more than six (6) meters at low tide (Ramsar, 2012). Wetlands as coastal ecosystems (onshore and offshore) are among the world's most biologically productive ecosystems (only comparable to tropical rainforests and coral reefs) based on the diversity of biological and native species. However, the manner and process of exploiting the natural resource base by anthropogenic activities influences the state of environmental components (air, water and land), size or hectares covered by wetlands, fragmentation and extinction of habitable biological and native species which provide ecosystem services (GomezBageethun \& Barton, 2013; Millennium Ecosystem Assessment, 2015). For instance, different species of parrots and the palm-nut vulture which are uniquely and exclusively domiciled in the Niger Delta wetland are threatened by urban growth activities (Millennium Ecosystem Assessment, 2015).

Wetland ecosystems are important from conservation and sustainable management of the ecosystem because of their rich diversity of flora and fauna. Tangible and intangible diverse resources and products of wetland functions such as fodder, fishes, fuel wood, non timber forest products, ecotourism, and flood control have historically provided a source of income and livelihood for human beings.

In spite of the significant role of wetlands to the environment we live in, most of the world's wetlands have been lost due to series of human activities especially, hydrologic alteration, urbanization, agriculture etc which have continued to degrade this distinct element of ecosystem. Most members of the public regard wetland as unproductive and unhealthy lands. This view has led to over half of the world wetlands being degraded. This tremendous loss is a serious concern to human being and the environment (Albakri, Duqqah \& Brewer, 2013).

The reduction in the mass and eventual loss of wetlands the world over damages the health and well-being of individuals and local communities and diminishes their development prospects (Millennium Ecosystem Assessment, 2015). The problem is particularly severe in countries that have weak policy and management strategies like Nigeria. It is in the light of this that this study focused on assessing the extent and rate of wetland loss in Port Harcourt Metropolis.

\section{STATEMENT OF THE PROBLEM}

Wetlands as one of the world's most important resources provide many environmental and socioeconomic benefits to human beings and the general ecosystem. Despite the significant roles of wetlands to man and his environment, most of the wetlands in Port Harcourt have been lost due to series of human activities especially, hydrologic alteration and urbanization. Although, several studies have been done to determine the level of wetland loss in Niger Delta, there is no 
International Journal of Agriculture and Environmental Research

ISSN: 2455-6939

Volume: 07, Issue: 06 "November-December 2021"

systematic, holistic and integrated approach to determine wetland loss in the study area. Moreover, no time series of spatial variation of wetland loss in the study area has been conducted. Therefore, the following research questions were posed to guide this study;

i) What is the extent and rate of wetland loss in the study area between 1990-2020?

ii) What is the estimate of the probability of change in wetlands and other land-use in the next 30 years (2050)?

iii) How can sustainable wetland protection be achieved in the study area?

\section{LITERATURE REVIEW}

\section{Concept of Wetland}

Wetland is an ecosystem that arises when inundation by water produces soils dominated by anaerobic processes, which in turn, forces the biota, particularly rooted plants, to adapt to flooding” (Mitsch \& Gosselink, 2015). McCarteny, Rebelo, Senaratna, Sellamuttu and de Silva (2010) assert that wetlands are sinks into which surface waters or groundwater flows from a surrounding catchment. They are sites where water occurs at or close to the ground surface. Ramsar (2012), described wetland as the interfacial ecosystem located between terrestrial ecosystem and aquatic ecosystems leading or manifesting to acetones

Similarly, the United States Environment Protection Agency (USEPA, 2011) define wetlands as land areas covered with water or where water is present at or near the soil surface all year or varying periods of the year. Kadziya and Chikosha (2013), defined wetlands as lands where saturation with water is the dominant factor determining the nature of the soil development, types of soil development and the types of plant and animal community living in the soil and on the surface, and generally includes swamps, marshes, bogs and similar areas. These definitions depict wetlands as an ecosystem with services that are very important to the sustenance of both the surface and groundwater resources of the earth.

Desta, Lemma and Fetene (2012) pointed out that wetlands (even in the Niger Delta region) are among the ecosystems most vulnerable or susceptible to uncoordinated anthropogenic activities. The large influx of industries has led to urban growth and expansion into wetland because of need for land and new housing (Zubair, Ji, \& Weilert, 2017

A large percentage of wetlands have been degraded, converted and lost in the last century, apparently due to drainage and land clearance, and other urban and industrial development activities. It is in realization of the eminent threats and consequences of uncoordinated human and natural factors that accompany destruction of wetland ecosystems as important natural 
International Journal of Agriculture and Environmental Research

ISSN: 2455-6939

Volume: 07, Issue: 06 "November-December 2021"

habitat that eventually, prompted the world's response in 1971 to hold a conference at the Iranian city of Ramsar otherwise known as Ramsar Convention on Wetlands of International Importance (Rasmar, 2012). This is in order to chart a way forward towards change in attitude relating to wetlands and advocacy on the wise use of wetlands. Hence, prioritizing the wise use of wetlands entails integrating a multi-disciplinary approach, mechanism and procedure into the planning and execution of projects targeted at conserving wetlands (Rasmar, 2012).

\section{Loss of Wetland}

Perception of wetlands as wastelands, disastrous realms, custodians of diseases and obstacles to meaningful development is presumably responsible for the consequent sale, alteration/destruction, conversion, reclamation, and actual loss of wetlands into other commercial, industrial and residential purposes. The relatively few studies published to date show that land development is linked to declining wetland. For example, Hicks and Larson (1997) found that the wetland invertebrate community was impaired beyond 20\% impervious cover in the CDA, while wetlands with low CDA impervious cover (less than 5\%) were found to be similar to natural reference wetlands. In studies of Minnesota wetlands, wetland invertebrate community measures, including total abundance, were inversely correlated to urbanization (Gernes \& Helgen, 2002).

Ajibola, Adelek and Ogungbemi (2016) emphasized that much of the world's wetlands have been lost due to series of increasing urbanization and the subsequent human activities which gradually cause the degradation of this important subsystem of the general ecosystem which play vital roles in the sustenance of both the surface and groundwater resources of the earth. In other words, a wetland is considered to be lost if it has been converted to non-wetland area, degraded or developed to the extent that it has being impaired or lost a considerable amount of its natural functional values and supports, as-would occur if it was severely eroded or drained and planted to pastures.

Odine (2011) emphasized that poor understanding of economic and productive values of wetlands is a contributing factor to perceiving wetlands as wastelands warranting or deserving massive destruction. Similarly, activities that preludes rapid industrialization and urban development (land-use) are land clearing and land reclamation when poorly controlled creates major problems that often results in loss of wetlands.

\section{METHODOLOGY}

\section{Description of the Study}


The study was carried out Port Harcourt Metropolis, Rivers State. Geographical coordinates of Port Harcourt are $4^{0} 49^{\prime} 27^{\prime} \mathrm{N}$ and $7^{0} 21^{\prime} \mathrm{E}$. The climate of Port Harcourt metropolis falls within the sub equatorial belt. Temperature and humidity are high throughout the years. The area is marked by two distinct seasons-the wet and the dry seasons, with 70 percent of the annual rains falling between April and August, while 22 percent is spread in the three months of September to November. Rainfall is adequate for all year round crop production in the state.

In Port Harcourt metropolis, maximum monthly temperature ranges from $28^{\circ} \mathrm{c}$ to $33^{\circ} \mathrm{c}$, while the mean minimum monthly temperatures are in the range of $17^{\circ} \mathrm{c}$ to $24^{\circ} \mathrm{c}$. The mean monthly temperature is in the range of $25^{\circ} \mathrm{c}$ to $28^{\circ} \mathrm{c}$.Relative humility is high in the state, throughout the year and decreases slightly in the dry season.

The area predominantly lies in a flat terrain consisting of levels of gently undulated sandy plains but without areas of isolated depression. The soil type consists mainly of poorly-drained silt clays mixed with sand, which is geologically classified under the Benin formation. This soil is organic in nature. There is also mangrove swamp alluvial soil found north to the coastal sediments zone and they are brownish on the surface

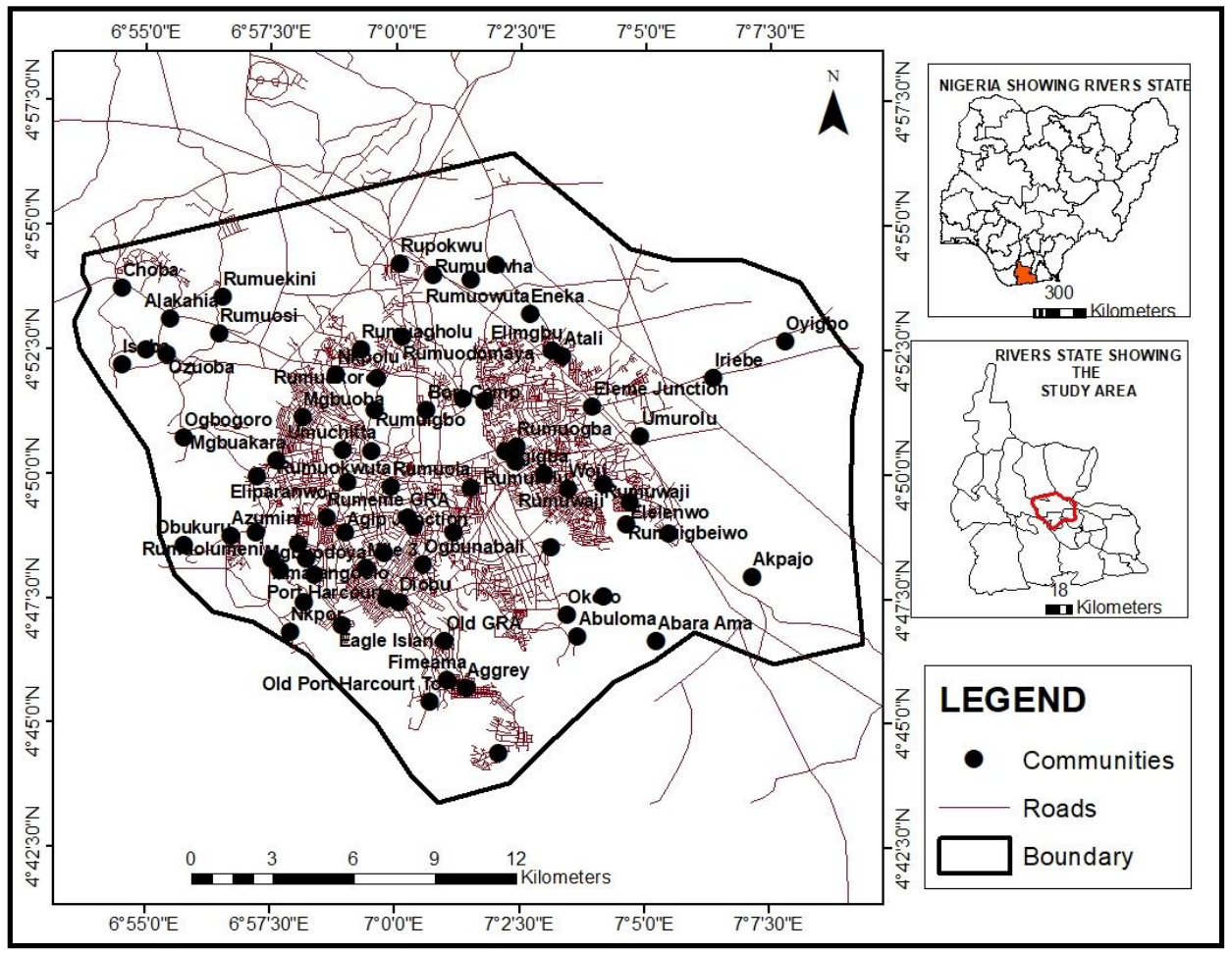

Figure 1: Map of theStudyarea

Source: Nigeria Local Government Administrative Map (2021) 
International Journal of Agriculture and Environmental Research

ISSN: 2455-6939

Volume: 07, Issue: 06 "November-December 2021"

Port Harcourt metropolis is influenced by urbanization or urban sprawl-where by smaller communities are beginning to merge together to form a megacity. As at 2009 her population was about 2 million (Nwankwoala, 2012).

\section{Nature and Sources of Data}

The study employed the use of both primary and secondary data. The primary data consists mainly of GPS data While secondary comprises mostly of satellite imagery, digital maps and related literatures. The study made use of Landsat imageries of Port Harcourt Metropolis of 1990, 2000 and 2020 at 30m by 30m resolution acquired from the USGS. Reconnaissance survey was carried out to ascertain and ground truth the wetland locations. Global Positioning System (GPS) was used to determine the locations of wetlands and other land-uses in Port Harcourt Metropolis. During the survey, the major land-uses identified included built up area, wetland, farmlands/Sparse vegetation, water bodies, and thick vegetation.

\section{METHOD OF DATA ANALYSIS AND PRESENTATION}

\section{Land-use/Landcover Analysis and Wetland Mapping}

Training sites were created on each imagery whereby, similar spectral reflectances were captured and grouped together to generate signature file for the classification. Maximum likelihood supervised classifications were performed in ERDAS IMAGINE 9.2 on the landsat imagery. The per-pixel supervised classifications grouped satellite image pixels with the same or similar spectral reflectance features into the same information categories. The purpose of this imagery in this study is to serves as guideline for land use/land cover mapping of the area in order to authenticate the result apart from accuracy assessment. This imagery was got from National Space Research and Development Agency (NASRDA).

Five classes of land use/ cover were identified in this study namely built up area, wetland, water bodies, farmland/sparse vegetation and thick vegetation. The description of each of the classes is shown in Table 1. The classified land-use imagery were then converted to vector format to calculate the area of land-uses which included wetlands in each year in squared kilometers using spatial query module in ArcGIS 10.8. The wetlands were separated from other land-uses to generate a spatial distribution map of wetlands in Port Harcourt Metropolis.

The spatial extent of land-use in each year was calculated and simple arithmetic was done by subtracting the area of wetland in initial year from the final year. The difference gives the landuse change in terms of spatial coverage and direction of changes. The percentage change of landuse was then computed to determine the percentage increase or decrease of land-use in Port Harcourt Metropolis using the formula: LU Initial - LU Final/LU Initial x 10 
The probability of wetlands changing to another land-use and vice versa was determined and predicted to 2030 (10 years), 2040 (20 years) and 2050 (30 years) using Markovian's Transition Estimator in Idrisi Selva change per year under consideration.

Table 1: Landuse/Landcover Classification Scheme

\begin{tabular}{|c|c|c|}
\hline S/N & Landuse Types & Description \\
\hline 1 & Thick vegetation & $\begin{array}{l}\text { Thick forest, Derived forest, mixed forest lands, palms, } \\
\text { conifer, schrubs, herbs and others }\end{array}$ \\
\hline 2 & Built Up Area & $\begin{array}{l}\text { Residential, commercial and services, industrial, } \\
\text { transportation, roads }\end{array}$ \\
\hline 3 & Wetlands & $\begin{array}{l}\text { Permanent and seasonal wetlands, low-lying areas, } \\
\text { marshy land, rills and gully, swamps }\end{array}$ \\
\hline 4 & Water bodies & $\begin{array}{l}\text { Rivers, permanent open water, lakes, ponds, reservoirs, } \\
\text { etc }\end{array}$ \\
\hline 5 & $\begin{array}{l}\text { Farmland/Sparse } \\
\text { vegetation }\end{array}$ & $\begin{array}{l}\text { agricultural area, crop fields, fallow lands and vegetable } \\
\text { lands }\end{array}$ \\
\hline
\end{tabular}

Source: Researcher's Analysis, 2020

Descriptive statistics was used to explain the values of wetland and other land-use change and their percentage change per year under consideration. Results were presented using maps, tables and graphs.

\section{RESULTS AND DISCUSSION}

\section{The Trend and Rate of Wetland Loss in the Study Area Between 1990-2020}

Land-use land cover classification of the study area in 1990-2020 was produced to make sample collection and classification process easy in order to identify wetlands and other land uses. Among the land uses in the study area include; thick vegetation, built up area, wetland, water bodies and farmland/sparse vegetation. 
International Journal of Agriculture and Environmental Research

ISSN: 2455-6939

Volume: 07, Issue: 06 "November-December 2021"

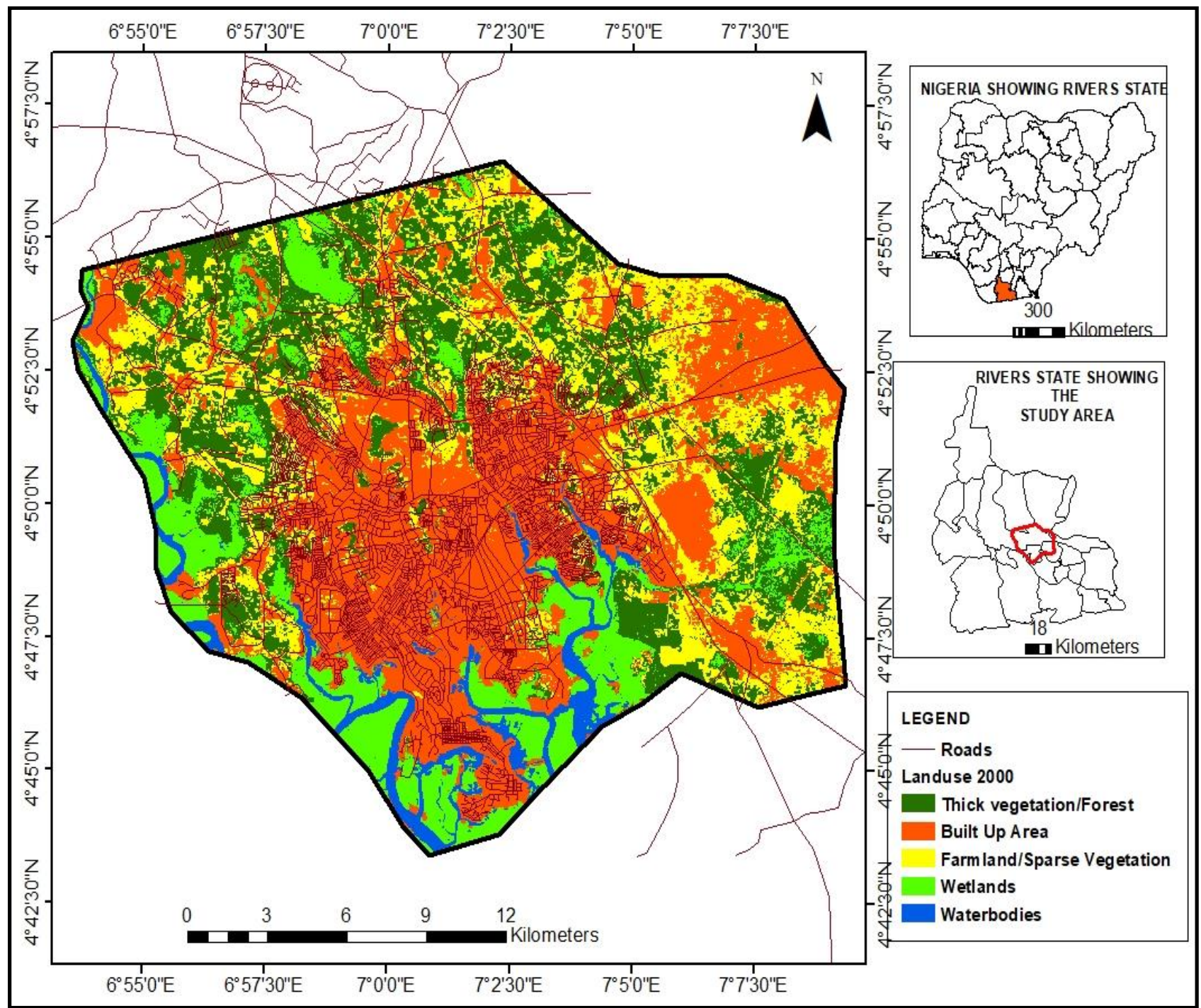

Figure 2: Land-use land cover map of the study area 1990

Source: Researcher's Fieldwork / GIS Analysis 2012 
International Journal of Agriculture and Environmental Research

ISSN: 2455-6939

Volume: 07, Issue: 06 "November-December 2021"

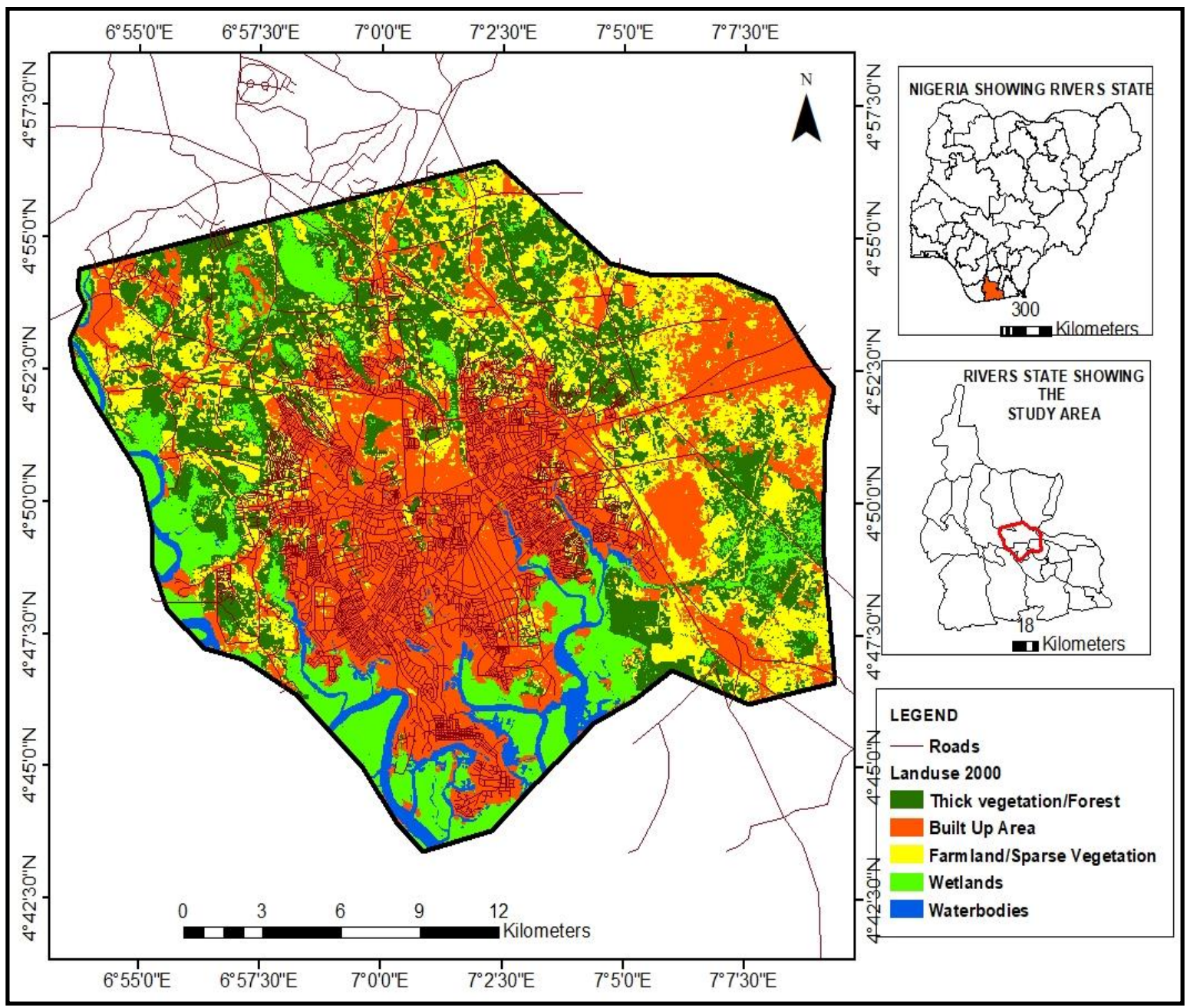

Figure 3: Land-use land cover map of the study area 2000

Source: Researcher's Fieldwork / GIS Analysis, 2021 
International Journal of Agriculture and Environmental Research

ISSN: 2455-6939

Volume: 07, Issue: 06 "November-December 2021"

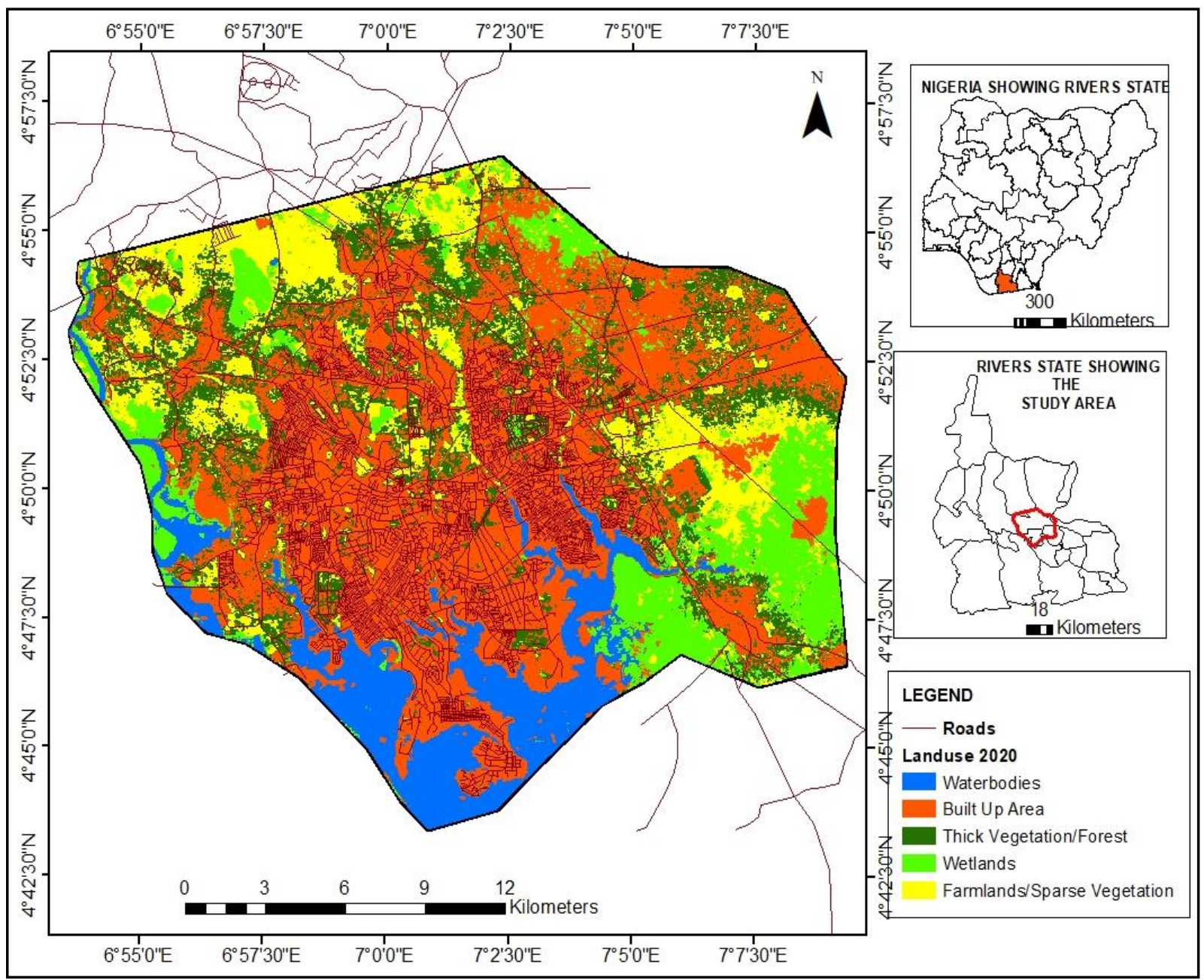

Figure 4: Land-use land cover map of the study area 2020

Source: Researcher's Fieldwork / GIS Analysis, 2021

Data in Table 2 shows the trend and rate of wetland loss in the study area between 1990-2020 among other land-uses. 
International Journal of Agriculture and Environmental Research

ISSN: 2455-6939

Volume: 07, Issue: 06 "November-December 2021"

Table 2: Trend and Rate of Wetland Loss Among Other Land-uses in 1990, 2000, and 2020

\begin{tabular}{lcccccc}
\hline Land-use & $\begin{array}{l}\mathbf{1 9 9 0} \\
\left(\mathbf{k m}^{2}\right)\end{array}$ & $\begin{array}{l}\text { Percentage } \\
(\boldsymbol{\%})\end{array}$ & $\begin{array}{l}\mathbf{2 0 0 0} \\
\left(\mathbf{k m}^{2}\right)\end{array}$ & $\begin{array}{l}\text { Percentage } \\
(\boldsymbol{\%})\end{array}$ & $\begin{array}{l}\mathbf{2 0 2 0} \\
\left(\mathbf{k m}^{2}\right)\end{array}$ & $\begin{array}{l}\text { Percentage } \\
(\boldsymbol{\%})\end{array}$ \\
\hline Thick vegetation & 119.52 & 26.08 & 103.92 & 22.68 & 89.13 & 19.45 \\
Built Up Area & 85.14 & 18.58 & 167.53 & 36.56 & 213.09 & 46.50 \\
Wetland & $\mathbf{1 2 3 . 2 3}$ & $\mathbf{2 6 . 8 9}$ & $\mathbf{7 6 . 4 1}$ & $\mathbf{1 6 . 6 8}$ & $\mathbf{4 4 . 6 1}$ & $\mathbf{9 . 7 4}$ \\
Water bodies & 28.25 & 6.17 & 19.96 & 4.36 & 48.62 & 10.61 \\
$\begin{array}{l}\text { Farmland/Sparse } \\
\text { vegetation }\end{array}$ & 102.08 & 22.28 & 90.4 & 19.73 & 62.77 & 13.70 \\
Total & $\mathbf{4 5 8 . 2 2}$ & $\mathbf{1 0 0 . 0 0}$ & $\mathbf{4 5 8 . 2 2}$ & $\mathbf{1 0 0 . 0 0}$ & $\mathbf{4 5 8 . 2 2}$ & $\mathbf{1 0 0 . 0 0}$ \\
\hline
\end{tabular}

Source: Researcher's Analysis, 2021

The major land-use types identified in the study area alongside wetlands included built up area, water bodies, farmland/sparse vegetation and thick vegetation from 1990 to 2020 (Figures 2-4).

Table 2 showed that in 1990, the wetland occupied a spatial extent of $123.23 \mathrm{~km}^{2}(26.89 \%)$. The results for the year 2000 showed that wetland size decreased to $76.41 \mathrm{~km}^{2}(16.68 \%)$. Consequently, in year 2020, there was further decrease in wetland size to $44.61 \mathrm{~km}^{2}(9.74 \%)$.

The analysis reveals that the wetlands recorded the highest spatial extent in 1990. Wetland recorded only $16.68 \%$ of the total spatial extent of the entire area. Wetland in the year 2020 decreased further by $6.94 \%$. The result reveals a progressive loss in wetland in the study area. This is in line with the findings of Orimoogunje, Oyinloye and Soumah (2009), which asserted a continued reduction in the area coverage of wetlands in Nigeria and attributed it mainly to urbanization.

Estimated Probability of Change in Wetlands and Other Land-uses in the Study Areas in the Next 30 years

Tables below showed the probability of estimated change in wetland and other land uses of the study area in the next 30 years. 
International Journal of Agriculture and Environmental Research

ISSN: 2455-6939

Volume: 07, Issue: 06 "November-December 2021"

Table 3: Markov's Probability of Land-use Change in 2030

\begin{tabular}{llllll}
\hline Land-use & $\begin{array}{l}\text { Thick } \\
\text { vegetati } \\
\text { on }\end{array}$ & $\begin{array}{l}\text { Built } \\
\text { Up } \\
\text { Area }\end{array}$ & $\begin{array}{l}\text { Farmland/ } \\
\text { Sparse } \\
\text { vegetation }\end{array}$ & Wetland & $\begin{array}{l}\text { Water } \\
\text { bodies }\end{array}$ \\
\hline Thick vegetation & 0.4334 & 0.2795 & 0.2815 & 0.0055 & 0.0001 \\
$\begin{array}{l}\text { Built Up Area } \\
\begin{array}{l}\text { Farmland/Sparse } \\
\text { vegetation }\end{array}\end{array}$ & 0.0602 & 0.9127 & 0.0022 & 0.0157 & 0.0092 \\
$\begin{array}{l}\text { Wetland } \\
\text { Waterbodies }\end{array}$ & 0.1814 & 0.6220 & 0.0194 & 0.0000 \\
& 0.0003 & 0.0001 & 0.0024 & 0.2076 & 0.7896 \\
\hline
\end{tabular}

Source: Researcher's Field Analysis, 2021

Table 4: Markov's Probability of Land-use Change in 2040

\begin{tabular}{llllll}
\hline Land-use & $\begin{array}{l}\text { Thick } \\
\text { vegetation }\end{array}$ & $\begin{array}{l}\text { Built } \\
\text { Area }\end{array}$ & $\begin{array}{l}\text { Farmland/Sparse } \\
\text { vegetation }\end{array}$ & Wetland & $\begin{array}{l}\text { Water } \\
\text { bodies }\end{array}$ \\
\hline Thick vegetation & 0.2967 & 0.3547 & 0.2857 & 0.0475 & 0.0154 \\
Built Up Area & 0.0553 & 0.9011 & 0.0025 & 0.0221 & 0.0019 \\
$\begin{array}{l}\text { Farmland/Sparse } \\
\text { vegetation }\end{array}$ & 0.1846 & 0.2962 & 0.4456 & 0.0716 & 0.0020 \\
Wetland & & & & & \\
Waterbodies & $\mathbf{0 . 2 4 2 2}$ & $\mathbf{0 . 2 5 7 4}$ & $\mathbf{0 . 3 5 0 0}$ & $\mathbf{0 . 1 4 8 9}$ & $\mathbf{0 . 0 0 1 5}$ \\
& 0.0001 & 0.0049 & 0.0012 & 0.4378 & 0.5560 \\
\hline
\end{tabular}

Source: Researcher's Field Analysis, 2021 
International Journal of Agriculture and Environmental Research

ISSN: 2455-6939

Volume: 07, Issue: 06 "November-December 2021"

Table 5: Markov's Probability of Land-use Change in 2050

\begin{tabular}{llllll}
\hline Land-use & $\begin{array}{l}\text { Thick } \\
\text { vegetation }\end{array}$ & $\begin{array}{l}\text { Built } \\
\text { Up } \\
\text { Area }\end{array}$ & $\begin{array}{l}\text { Farmland/Sparse } \\
\text { vegetation }\end{array}$ & $\begin{array}{l}\text { Wetlan } \\
\text { d }\end{array}$ & Waterbody \\
\hline Thick vegetation & 0.2527 & 0.4706 & 0.2588 & 0.0170 & 0.0009 \\
Built Up Area & 0.0761 & 0.8823 & 0.0174 & 0.0235 & 0.0007 \\
$\begin{array}{l}\text { Farmland/Sparse } \\
\text { vegetation }\end{array}$ & 0.1830 & 0.3849 & 0.4251 & 0.0070 & 0.0000 \\
$\begin{array}{l}\text { Wetland } \\
\text { Waterbodies }\end{array}$ & $\mathbf{0 . 2 1 0 5}$ & $\mathbf{0 . 3 2 8 9}$ & $\mathbf{0 . 3 1 1 3}$ & $\mathbf{0 . 1 2 2 2}$ & $\mathbf{0 . 0 2 7 1}$ \\
\hline
\end{tabular}

Source: Researcher's Field Analysis, 2021

The analysis from Tables 3 to 5, show the Markov's probability of a land-use changing to another land-use in the next 10 years (2030), 20 years (2040) and 30 years (2050). In Table 3, it is revealed that by 2030, the probability of a thick vegetation land-use changing to built up area is $0.2795(27.95 \%)$, to farmland/sparse vegetation is $0.2815(28.15 \%)$, to wetland is 0.0055 $(0.55 \%)$ and to water-bodies is $0.0001(0.01 \%)$. For the built up area, the probability of it changing to thick vegetation is $0.0602(6.02 \%)$, changing to wetland is low $(0.0157(1.57 \%)$, and water bodies is also low $(0.0092(0.92 \%)$. The probability of farmland/sparse vegetation changing to thick vegetation is $0.1772(17.72 \%)$, the probability of the same land-use changing to built up area is $0.1814(18.14 \%)$, while the probability of it changing to wetland or water bodies is $0.0194(1.94 \%)$ and $0.0000(0 \%)$ respectively.

Furthermore, the probability of wetland changing to other land-uses, predicted 0.1564 (15.64\%) for thick vegetation, 0.1351 (13.51\%) for built up area, for farmland/sparse vegetation is 0.0271 $(2.71 \%)$, while the probability of it changing to waterbodies is $0.0354(3.54 \%)$. For waterbodies, the probability of it changing to thick vegetation, built up area and a farmland/ sparse vegetation is very low, while the probability of it becoming a wetland is $0.2076(20.76 \%)$.

Table 4 predicts that in the next 20 years (2040), the tendency for thick vegetation to likely change to built up area is 0.3547 (35.47\%), for it to change to farmland/sparse vegetation is 0.2857 (28.57\%), to wetland will be 0.0475 (4.75\%) and 0.0154 (1.54\%) for it to changing to waterbodies. For built up area, the probability level of it changing to thick vegetation is 0.0553 (5.53\%), to farmland/sparse vegetation is $0.0025(0.25 \%)$, probability of it changing to wetland is $0.0221(2.21 \%)$, and $0.0019(0.19 \%)$ to a waterbodies. The tendency of a farmland/sparse 
International Journal of Agriculture and Environmental Research

ISSN: 2455-6939

Volume: 07, Issue: 06 "November-December 2021"

vegetation to change to thick vegetation is $0.1772(17.72 \%)$, to built up area is $0.1814(18.14 \%)$, while the probability of it changing to wetland and waterbodies is $0.0194(1.94 \%)$ and 0.000 $(0 \%)$ respectively. The wetlands' probability of changing to thick vegetation in 20 years time is $0.1564(15.64 \%)$, tendency of it changing to built up area is $0.1351(13.51 \%)$, to farmland/sparse vegetation is $0.0271(2.71 \%)$ which is the highest probability level, and $0.0354(3.54 \%)$ for it changing to waterbodies. Lastly, the probability of waterbodies changing to thick vegetation is $0.0003(0.03 \%)$, for waterbodies to change to built up area is $0.0001(0.001 \%)$, and not also probable for it changing to farmland/sparse vegetation is $0.0024(0.24 \%)$, and relatively high for it changing to wetland which is $0.2076(20.76 \%)$.

In addition, Table 5 showed the Markov's probability of land-use change for 30 years (2050). The statistics showed that the probability of thick forest changing to a built up area is 0.2967 (29.67\%), 0.2857 (28.57\%) probability for it changing to a farmland/sparse vegetation, 0.0475 (4.75\%) for it changing to wetland and $0.0154(1.54 \%)$ for waterbodies. For built up area, the probability level of the land-use changing to thick vegetation is 0.0553 (5.53\%), to farmland/sparse vegetation is $0.025(0.25 \%)$, to wetland is $0.0221(2.21 \%)$, and $0.0019(0.19 \%)$ for it changing to waterbodies. Likewise, farmland/sparse vegetation will likely change to thick vegetation with probability level of 0.1846 (18.46\%), to built up area is $0.2962(29.62 \%)$, to wetland is $0.0716(7.16 \%)$ and not likely for it to change to a waterbodies $(0.0020(0.20 \%))$. However, the wetlands in the study area have $0.2422(24.22 \%)$ tendency of changing to built up area and also, the likelihood to change to farmland/sparse vegetation is $0.3500(35.0 \%)$, and not likely to change to a waterbodies $(0.15 \%)$. On the other hand, waterbodies have a strong probability to change to a wetland $(43.78 \%)$, when compared to the other landuse/landcover. The probability for it changing it to thick vegetation is low (0.0001), to a built up area is 0.0049 $(0.49 \%)$, and the probability of it changing to farmland/sparse vegetation is very unlikely (0.0012).

\section{CONCLUSION AND RECOMMENDATION}

The study as revealed from the classified imagery of wetland in the study area, there has been a continued loss of wetland. Nevertheless, a chunk percentage of wetland can still be found in Port Harcourt Metropolis. In other words, much of the wetlands in the study area have been degraded, sand filled/reclaimed, converted to other land uses or in the verge of being completely lost due to urban expansion or urban sprawl. The study also showed the estimated probability of land-use change in the study area. The study recommended that adequate and continuous monitoring of wetland by making use of satellite remote sensing should be encouraged in the study area. Also, there should be wetland and protection management policies with adequate enforcement mechanism. 
International Journal of Agriculture and Environmental Research

ISSN: 2455-6939

Volume: 07, Issue: 06 "November-December 2021"

\section{REFERENCES}

[1] Albakri, J. I., Duqqah, M. \& Brewer, T. (2013). Application of remote sensing and GIS for modeling and assessment of land use/cover change in Amman/Jordan J. Geogr. Inform. Syst., 5, 509-519.

[2] Ajibola, M.O., Adeleke, A.M. \& Ogungbemi, O. A. (2016). An assessment of wetland loss in Lagos metropolis, Nigeria. Development Country Studies, 6(7), 1-7.

[3] Desta, L., Lemme, Z. \& fetene, M. (2012). Gap analysis and conservation network for freshwater wetlands in Central Yangtze Eco-region. The Scientific World Journal, 2(3), 24-32

[4] Gerne, S., \& Helgen, B. (2002). Uncovering the ecosystem service legacies of wetland loss using high-resolution models. Ecosphere, 2(2). 53-64.

[5] Gomez-Bageethum, B. \& Barton, J. H. (2013). Economic values and dominant providers of key ecosystem services of wetlands in Beijing, China. Ecological Indicators, 7(7) 4858.

[6] Hicks, D., \& Larson, S (1997).Urban Development Consequences on the Wetland Ecosystems Transformation, Case Study PancevackiRit, Serbia. Contemporary Problems of Ecology 2(11), 16-28.

[7] Kadziya, L. \& Chikosha, F. (2013). Wetlands and urban growth in Bndura, Zimbabwe. Greener Journal of Environmental Management and Public Safety, 2(6), 195- 196.

[8] McCartney, R., Rebelo, S., \& Scluther, W.T. (2010). The emergence of ecosystem management as a tool for meeting People's needs and sustainable ecosystem. Landscape and urban planning, 3(2), 56-69.

[9] Millennium Ecosystem Assessment (2015). Ecosystems and human wellbeing: Our human planet. Washington DC: World Resources Institute.

[10] Mitsh, W. J. \& Gosseliink, J. G. (2015). Wetlands in Florida. London: John Wiley \& Sons, Inc.

[11] Nwankwoala, H. O. (2012). Case study of coastal wetlands and water resources in Nigeria. European Journal of Sustainable Development.

[12] Odine, R. (2011). The spatial distribution of development in Europe and its underlying sustainability correlation. Applied Geography, 63, 304-314.

[13] Orimoogunje, O.O.I.; Oyinloye, R. O. \& Soumah, M. (2009) (2009) Geospatial Mapping of Wetlands Potential in Ilesa, Southwestern Nigeria. Journal of Business and Social Sciences, 4, 234-243..

[14] Ramsar, (2012). Principles for the planning and management of urban and peri-urban wetlands. Bucharest: Urban Wetlands Pub.

[15] Tijani, M. N.; Olaleye, A. O. \& Olubanjo, O.O. (2011). Impact of urbanization on wetland degradation: A case study of Eleyele wetland, Ibadan, South west, Nigeria. 
International Journal of Agriculture and Environmental Research

ISSN: 2455-6939

Volume: 07, Issue: 06 "November-December 2021"

Proceedings of the Environmental Management Conference, Federal, University of Agriculture, Abeokuta, Nigeria, 435-457.

[16] Zubair, O.A., Ji, W. \& Weilert, T.E. (2017) Modeling the Impact of Urban Landscape Change on Urban Wetlands Using Similarity Weighted Instance-Based Machine Learning and Markov Model. MDPI Sustainability Journal, 2(8), 42-32. 